Proc. Estonian Acad. Sci. Eng., 2002, 8, 3, 189-203

\title{
Flow modelling in the Pärnu Bay and the Kihnu Strait
}

\author{
Ülo Suursaar, Tiit Kullas, and Mikk Otsmann \\ Estonian Marine Institute, Tartu University, Paldiski mnt. 1, 10137 Tallinn, Estonia; ys@ sea.ee \\ Received 8 February 2002, in revised form 28 May 2002
}

\begin{abstract}
Flow features are studied in the NE part of the Gulf of Riga using a 2D hydrodynamic model forced by the wind and sea level data of 1999 as well as by some constructed stationary winds. Two flow patterns dominate in the Pärnu Bay. The most frequent of them has an inflow along the Liu and Tahkuranna coasts and an outflow along the trunk zone of the bay. Eastward motions predominate both in the Kihnu Strait and Valgerand. High flow velocities, participating (along with storm waves) in coastal erosion events, act 1-2 $\mathrm{m}$ above the average waterline and about half of the year's summary work of the flow by charging the coast is done during the 2-3 most stormy days of the year in the Pärnu Bay.
\end{abstract}

Key words: currents, storm surge, hydrodynamic model, water circulation, coastal engineering, Baltic Sea.

\section{INTRODUCTION}

Investigation of flow structures in the NE part of the Gulf of Riga is important in several aspects. Due to relatively large freshwater input from the Pärnu River, the mixing processes of the riverborne ingredients has considerable influence on the ecological situation of the Pärnu Bay $\left.{ }^{1}\right]$. Coastal processes may affect hydrotechnical constructions and operation of ports. The Pärnu Bay appears to be a hydrodynamically active marine area: due to shallowness, currents and waves cause resuspension and displacement of bottom sediments and occasional coastal erosion events occur during storms. Pärnu Bay has probably the highest measured storm surges (up to $+253 \mathrm{~cm}$ ) in the Baltic Sea except those in the Neva Bay near St. Petersburg and the region of Kiel and Schleswig $\left[{ }^{2}\right]$.

The model domain covers the whole Gulf of Riga and the Väinameri area (Fig. 1a), but the present case study is restricted to the marine area of about $1300 \mathrm{~km}^{2}$ (Fig. 1b). The maximum depth is $30 \mathrm{~m}$ in the $\mathrm{SW}$ part of the study 

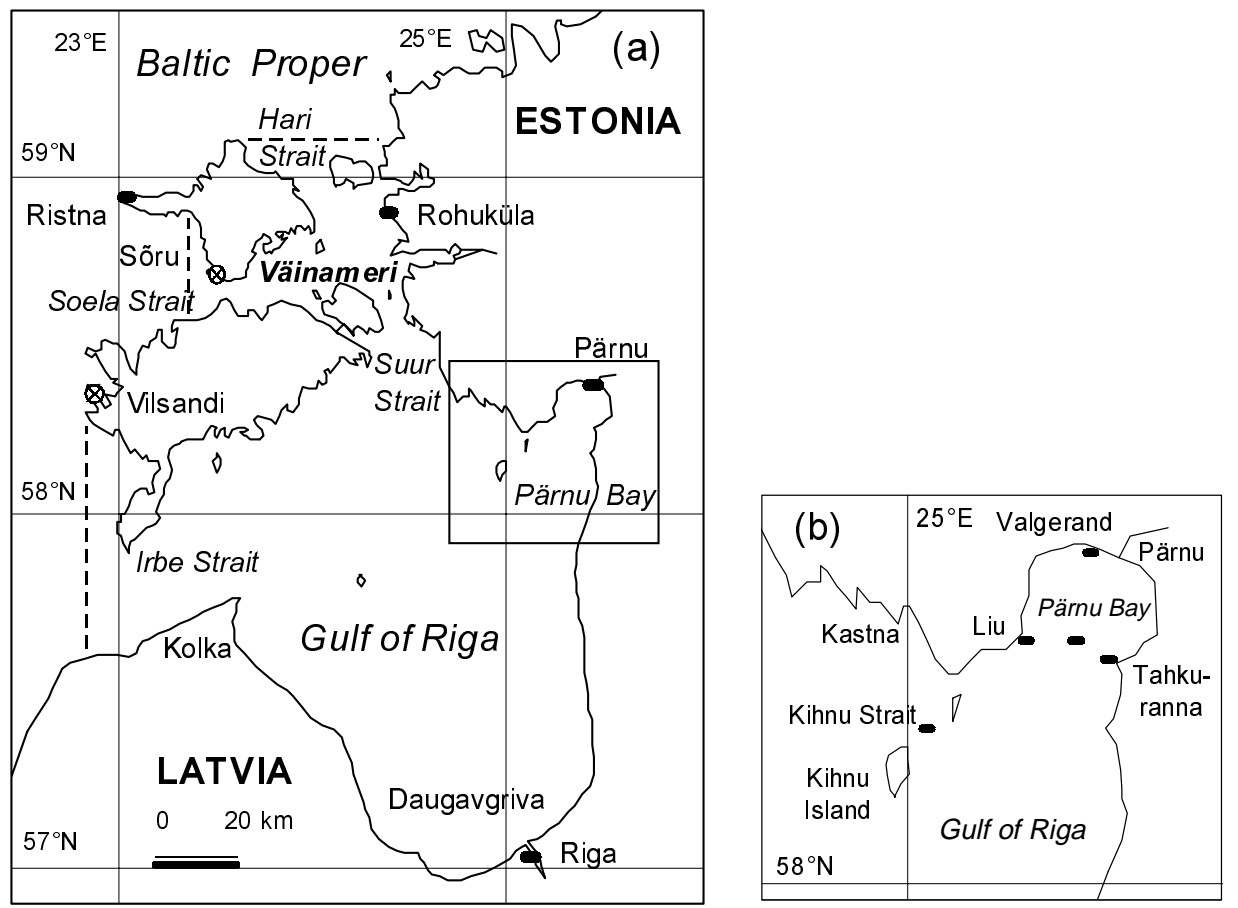

Fig. 1. The map of the region: Väinameri model with the open boundaries marked by dashed lines (a); the area of the case study (b).

area. Pärnu Bay is much more shallower, the inner bay (north from the LiuTahkuranna line) is approximately $14 \times 14 \mathrm{~km}^{2}$ with maximum depth of $7.6 \mathrm{~m}$ and volume of about $1 \mathrm{~km}^{3}$. The average annual freshwater inflow from the Pärnu River is about $2 \mathrm{~km}^{3}$. Between the Kihnu Island and the Estonian mainland, the $6 \mathrm{~km}$ wide Kihnu Strait is located. Its narrowest cross-section has an area of about $0.02 \mathrm{~km}^{2}$. Since January 2001, the aquatic environment of the strait together with the Kihnu Island and adjoining coastal landscapes of the mainland has been proclaimed as the Kihnu Strait Marine Park, a natural reserve of local importance $\left[^{3}\right]$. According to the integrated coastal zone management plan of this park, its incorporation into the international Ramsar Convention is foreseen.

The main aim of the paper is to describe the flow regime in the above-defined area and to discuss its influence on coastal environmental processes. Since in situ flow measurements are almost non-existent, the 2D hydrodynamic model data is used. The model is forced with realistic input data, but some additional simulations with constructed forcings are aimed at revealing typical flow patterns. Relying on the studies that proved the model's ability to simulate successfully flows in the straits of the Väinameri $\left[{ }^{4}\right]$ and the sea levels at several points of the Gulf of Riga and the Väinameri, including the Pärnu Bay $\left.{ }^{2,5}\right]$, we can also expect realistic performance of the model by describing general flow patterns in the NE corner of the Gulf of Riga. However, we do not consider small-scale flow 
features, which may appear as modelling artefacts. The inferences drawn from the data of the numerical simulations are quite general and of statistical character. The study is not aimed to the calculation of the sand movement as we do not have information about the grain size distribution, sediment availability, or layering properties. The wave field is not calculated either. The role of the waves is undoubtedly important in suspending sediments of the coastal zone. However, the longshore matter displacement is mainly determined by coastal currents.

\section{MODELLING METHODS}

\subsection{Hydrodynamic equations}

The 2D hydrodynamic model for the Gulf of Riga and Väinameri used in the study is a shallow sea depth-averaged barotropic free-surface model with quadratic bottom friction using $1 \mathrm{~km}$ grid step. It is composed of the momentum and continuity equations:

$$
\begin{gathered}
\frac{D U}{D t}-f V=-g(H+\xi) \frac{\partial \xi}{\partial x}+\frac{\tau_{x}}{\rho_{w}}-\frac{k U}{H^{2}}\left(U^{2}+V^{2}\right)^{1 / 2}, \\
\frac{D V}{D t}+f U=-g(H+\xi) \frac{\partial \xi}{\partial y}+\frac{\tau_{y}}{\rho_{w}}-\frac{k V}{H^{2}}\left(U^{2}+V^{2}\right)^{1 / 2}, \\
\frac{\partial \xi}{\partial t}+\frac{\partial U}{\partial x}+\frac{\partial V}{\partial y}=0, \\
\text { where } \frac{D}{D t}=\frac{\partial}{\partial t}+\frac{1}{H}\left(U \frac{\partial}{\partial x}+V \frac{\partial}{\partial y}\right) .
\end{gathered}
$$

The volume flows $(U$ and $V)$ are given as:

$$
U=\int_{\xi}^{H} u d z ; \quad V=\int_{\xi}^{H} v d z,
$$

where $u$ and $v$ are flow velocities in $x$ and $y$ directions, respectively, $\xi$ is the sea surface elevation (from the equilibrium depth, $H$ ), $\rho_{w}$ is water density, $f$ is Coriolis parameter, $k$ is the bottom stress coefficient $(k=0.0025)$, and $\tau_{x}$ and $\tau_{y}$ are wind stress components along the $x$ and $y$ axis. Wind stress $(\vec{\tau})$ was computed using the formula by Smith and Banke $\left.{ }^{6}\right]$ :

$$
\vec{\tau}=\rho_{\mathrm{a}} C_{D}\left|\vec{W}_{10}\right| \vec{W}_{10},
$$

where $\left|\vec{W}_{10}\right|$ is the wind velocity vector modulus at $10 \mathrm{~m}$ height above the sea level, $\rho_{\mathrm{a}}$ is air density, $C_{D}$ is a non-dimensional empirical function of the wind velocity at $10 \mathrm{~m}$ height: $C_{D}=\left(0.63+0.066\left|\vec{W}_{10}\right|\right) 10^{-3}$. 
The bathymetry of the Gulf of Riga has been adopted from the Latvian bathymetric database $\left[^{7}\right]$ and the depths of the Väinameri were interpolated from nautical maps. The model domain includes 18964 marine points, its relatively short open boundaries are slightly shifted outside the narrowest parts of the straits (Fig. 1a). The numerical solution of the equations was obtained with the finite difference method using integration time step $30 \mathrm{~s}$.

Model calibration was made by using comparison with the Helmholtz model $\left[{ }^{8}\right]$. Since both models use the same values for friction coefficients $k$ and $C_{D}$, a set of calibration simulations was performed for slight adjustment of the generalized measures of the straits. Comparison of the modelled sea levels with the measured tide-gauge data from Rohuküla and Pärnu was made on the basis of the data of the year $1999\left[^{5}\right]$. The Helmholtz model has been calibrated and validated using flow measurements in the straits in $1993-1995\left[^{8}\right]$.

\subsection{Forcing conditions and simulations}

Wind stress above the sea and the sea level data along the open boundaries are the major forcings in such relatively small and semi-enclosed marine areas. Some minor factors affecting sea levels, such as inverted barometer effect, local thermal expansion, precipitation and evaporation, are not taken into account, but they influence to a certain extent the open sea level data. Monthly average river inflow data (in total $32 \mathrm{~km}^{3} / \mathrm{yr}$ ) are applied for keeping the long-term water budget of the subbasins, including the $2 \mathrm{~km}^{3} / \mathrm{yr}$ input from the Pärnu River.

Several simulations were carried out. The first set used the realistic input data of 1999. Wind stress, calculated from the wind data of the Vilsandi meteorological station with a $6 \mathrm{~h}$ time step, was applied homogeneously on the model domain and hourly sea level time series obtained from the Sõru tide gauge (mareograph) were applied along the open boundaries (Fig. 1a) for providing hourly output throughout the year 1999. The possible influence of the sea ice in winter months has not been taken into account. Modelled time series of velocity components and sea levels used in this study are taken from four points in the Pärnu Bay and one point in the middle of the Kihnu Strait (Fig. 1b).

The second simulation set was carried out for investigation of the steady state flow and sea level patterns. Homogeneous and stationary wind with $20 \mathrm{~m} / \mathrm{s}$ modulus and the direction changing between 1 and 360 compass degrees was applied to the whole study area. The snapshots of the quasistationary flow patterns for different wind directions, presented in the study, include 1334 marine points in the Pärnu Bay and NE part of the Gulf of Riga. The cases with and without the Pärnu River hydrodynamic influence were analysed.

The present model includes non-linear (advection) terms, whereas the first version $\left[{ }^{4}\right]$, used by us for reproducing flows in the straits and sea level variations, did not. Some test runs, aimed at examining non-linear effects, revealed that the differences between the simulated sea level values obtained with linear and non-linear versions remained within \pm 1 to $2 \mathrm{~cm}$ in the case of stationary $20 \mathrm{~m} / \mathrm{s}$ wind forcing and yielded a relative error up to $3 \%$. The similar 
differences in velocities in three selected points (Kihnu Strait, Valgerand, and Central Pärnu Bay) were up to $\pm 10 \mathrm{~cm} / \mathrm{s}$ (with relative error usually below $5 \%$ and up to $10 \%$ in some cases). It was also found that non-linearity caused some lateral shift of the flow patterns in time in some offshore regions, whereas the flow patterns themselves retained their general shapes.

\section{RESULTS AND DISCUSSION}

\subsection{Flow features in 1999}

Figure 2 exhibits predominance of certain current directions determined relative to the coastal line and bottom topography. The statistics of the modelled flow velocities are presented in Table 1 . East is the positive direction for $\mathrm{W}-\mathrm{E}$ velocity component $u$ and north is the positive direction for $\mathrm{S}-\mathrm{N}$ velocity component $v$. The mean velocity components shown in Table 1 and the mean velocity modulus $\bar{M}$ are defined as follows:

$$
\begin{gathered}
\bar{u}_{E}=\frac{1}{N_{+}} \sum_{i=1}^{N} \frac{u_{i}+\left|u_{i}\right|}{2}, \quad \bar{u}_{W}=\frac{1}{N_{-}} \sum_{i=1}^{N} \frac{u_{i}-\left|u_{i}\right|}{2}, \quad \bar{v}_{N}=\frac{1}{N_{+}} \sum_{i=1}^{N} \frac{v_{i}+\left|v_{i}\right|}{2}, \\
\bar{v}_{S}=\frac{1}{N_{-}} \sum_{i=1}^{N} \frac{v_{i}-\left|v_{i}\right|}{2}, \quad \bar{u}=\frac{1}{N} \sum_{i=1}^{N} u_{i}, \quad \bar{v}=\frac{1}{N} \sum_{i=1}^{N} v_{i}, \quad \bar{M}=\frac{1}{N} \sum_{i=1}^{N}\left(u_{i}^{2}+v_{i}^{2}\right)^{1 / 2},
\end{gathered}
$$

where $N_{+}$and $N_{-}$are the counts (durations) of the particular directions, $N_{+}+N_{-}=N$ is equivalent to 1 year (8760 hours).

The mean velocities were not large, ranging between 6.9 and $10.9 \mathrm{~cm} / \mathrm{s}$ in the nearshore points and $3.6 \mathrm{~cm} / \mathrm{s}$ in the middle of the Pärnu Bay. However, the maximum velocities reached $90 \mathrm{~cm} / \mathrm{s}$ both in the Kihnu Strait (Fig. 2a) and near Valgerand (Fig. 2c). Such high velocities occurred during the December 18

Table 1. Flow velocity components $(\mathrm{cm} / \mathrm{s})$ and their frequencies $(\%)$ along different directions at chosen points during 1999 (Fig. 1b)

\begin{tabular}{lccccccccc}
\hline & $\bar{v}_{N}$ & $\bar{v}_{S}$ & $\bar{u}_{E}$ & $\bar{u}_{W}$ & $\bar{v}$ & $\bar{u}$ & $\bar{M}$ \\
\hline Kihnu St. velocity & 8.7 & 7.9 & 8.2 & 5.9 & -0.1 & 2.6 & 10.9 \\
Frequency & 47 & 53 & 60 & 40 & 100 & 100 & \\
Liu velocity & 9.0 & 5.1 & 4.7 & 2.5 & 3.5 & 1.9 & 7.9 \\
Frequency & 61 & 39 & 61 & 39 & 100 & 100 & \\
Tahkuranna velocity & 7.6 & 4.4 & 4.4 & 2.4 & 2.6 & 1.7 & 6.9 \\
Frequency & 58 & 42 & 60 & 40 & 100 & 100 & \\
Valgerand velocity & 0.3 & 0.4 & 8.9 & 6.8 & -0.1 & 2.8 & 7.9 \\
Frequency & 41 & 59 & 61 & 39 & 100 & 100 & \\
Central Bay velocity & 2.3 & 3.9 & 1.4 & 2.2 & -1.5 & -0.7 & 3.6 \\
Frequency & 40 & 60 & 42 & 58 & 100 & 100 &
\end{tabular}



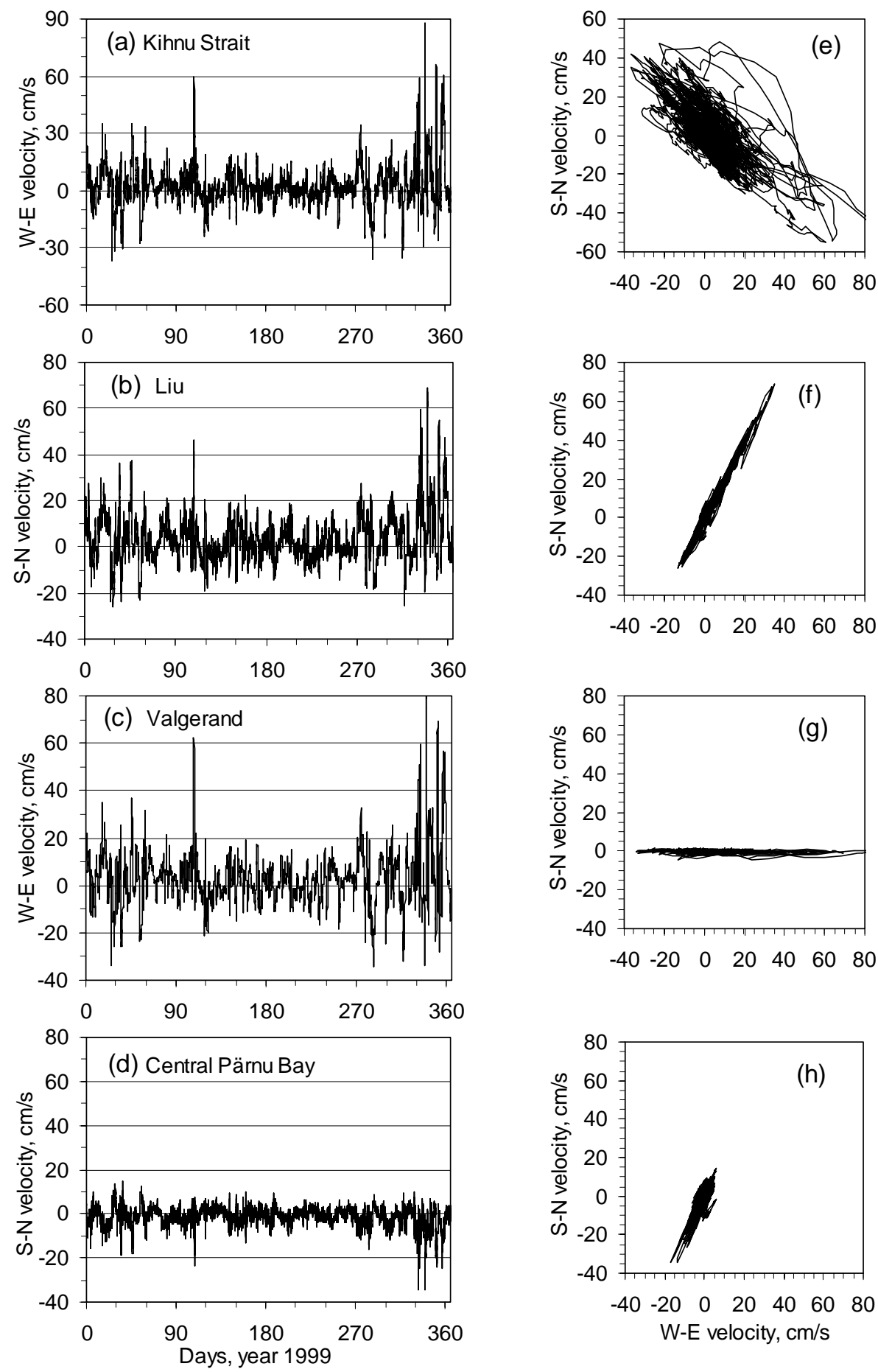

Fig. 2. Descriptive plots of time series of selected velocity components at the points (a)-(d) and plots of S-N vs W-E velocity components at these points in 1999. 
storm, which according to the Pärnu tide gauge data rised the sea level up to $146 \mathrm{~cm}$ above the Kronstadt zero benchmark. The study of corresponding sea level simulations included also a snapshot of flows during the peak of the storm surge $\left[{ }^{5}\right]$. Simultaneous coastal erosion events and retreat of the dune scarp for up to $5 \mathrm{~m}$ was reported by the Geological Survey of Estonia [ $\left.{ }^{9}\right]$.

There was a strong positive correlation between the W-E velocity components of the Kihnu Strait and the Liu S-N component $(r=0.84)$, as well as between the Liu S-N component and the Valgerand W-E component $(r=0.81)$. Evidently, a large portion of water, flowing eastwards through the Kihnu Strait, follows the coastal line to the north and then to the east, to Valgerand. The $\mathrm{S}-\mathrm{N}$ components of Liu and
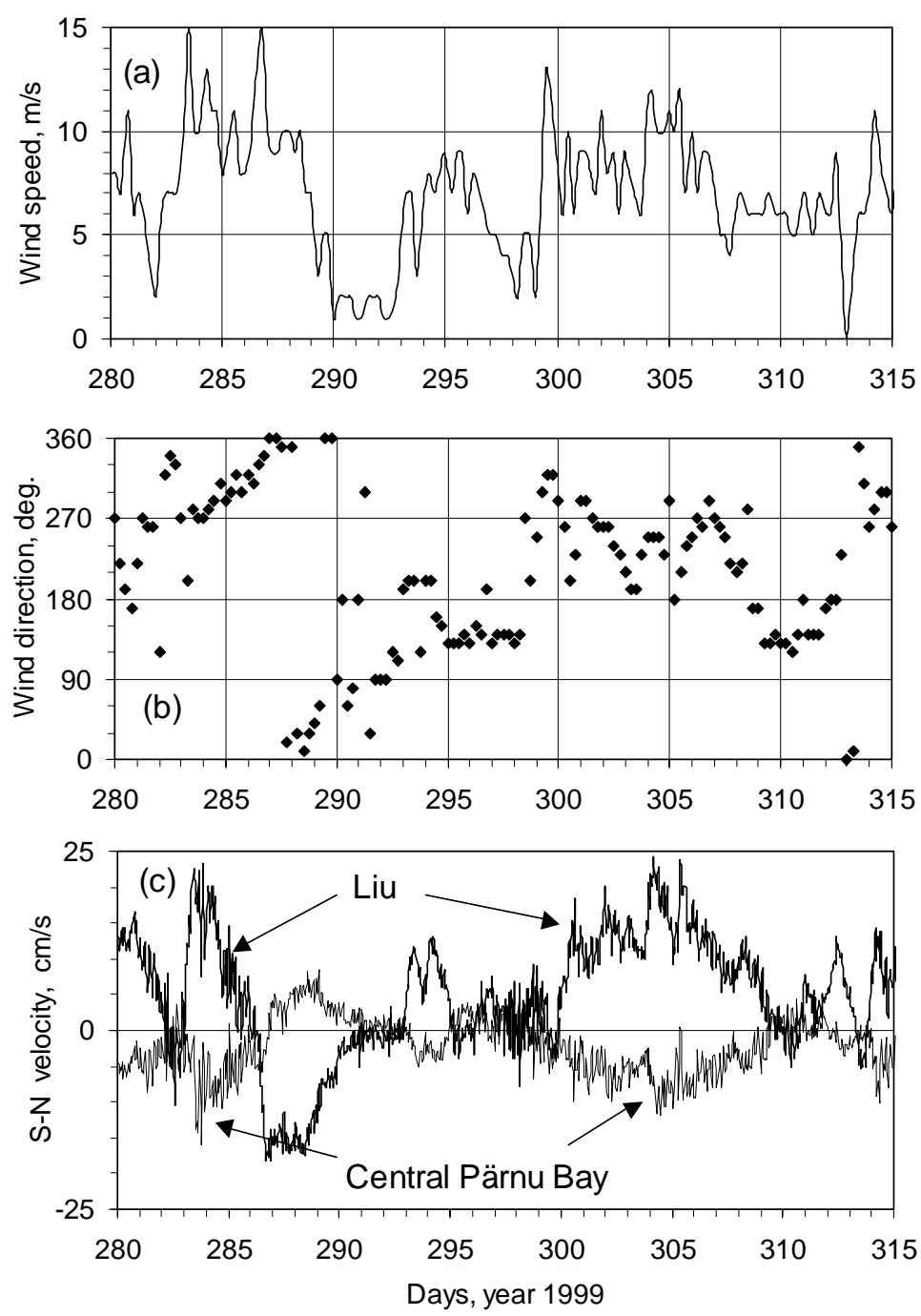

Fig. 3. Vilsandi wind forcing (a), (b) and corresponding flow velocities in the Pärnu Bay in autumn 1999 (c). 
Central Pärnu Bay velocities were negatively correlated $(r=-0.7)$ and similar correlation coefficient between Tahkuranna and Central Pärnu Bay was -0.6. Such a bidirectional flow regime in the Pärnu Bay and its dependence on wind conditions is also shown in Fig. 3. There seems to be two major contra-directional flow patterns in the bay, but the favoured one has inflows along the Liu and Tahkuranna coasts and outflow along the axis of the Pärnu Bay. The length of the cumulated S-N velocity components reached about $1000 \mathrm{~km}$ in Liu and Tahkuranna by the end of the year and the resultant flow was directed northwards (Fig. 4a), whereas the cumulative velocity was directed southward in the central Pärnu Bay yielding the length of nearly $500 \mathrm{~km}$ (Fig. 4b). These progressive curves of the current component
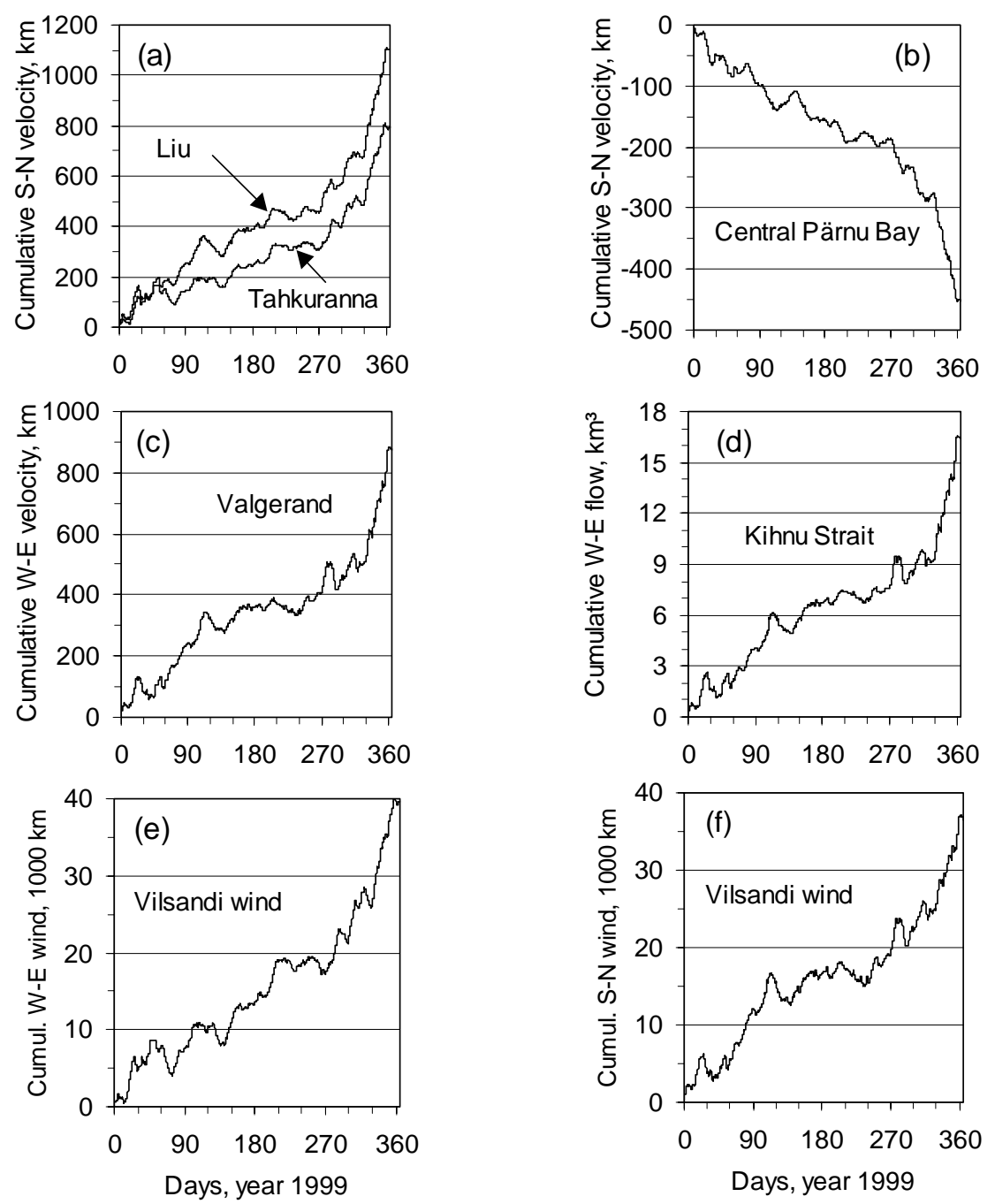

Fig. 4. Annual cumulative (integral) curves of current velocity components (a)-(c), volume fluxes (d), and wind vector components (e), (f). 
exhibited seasonality: the steep sections of curves in autumn and winter mark predominance of one regime over another and relatively level sections correspond to nearly equal occurrence of the regimes during spring and summer. The annual cumulative flow through the Kihnu Strait was $16 \mathrm{~km}^{3}$. All of that came from the W-E component (Fig. 4d), as the annual resultant S-N component appeared to be negligible (Table 1). The annual sum of individual flows in the SE direction was 31 and the similar sum for the NW direction of the strait was $15 \mathrm{~km}^{3}$.

The cumulative flow velocity curves were synchronous to the similar cumulative wind component's curves of Vilsandi (Fig. 4). Almost equal final values for the two wind components refer to prevailing SW winds during 1999.

\subsection{Stationary flow patterns}

Although the above flow statistics is valid mainly for the year 1999, it refers also to some general regularities. Simulations with constructed stationary and homogeneous wind conditions over the model domain revealed directional spans for different flow regimes (Fig. 5). Winds between $30^{\circ}$ and $210^{\circ}$ evoke NW currents in the Kihnu Strait and the rest of wind directions evoke eastward currents with maximum velocities of about $85 \mathrm{~cm} / \mathrm{s}$ (Fig. 5a,b). The corresponding 2D flow
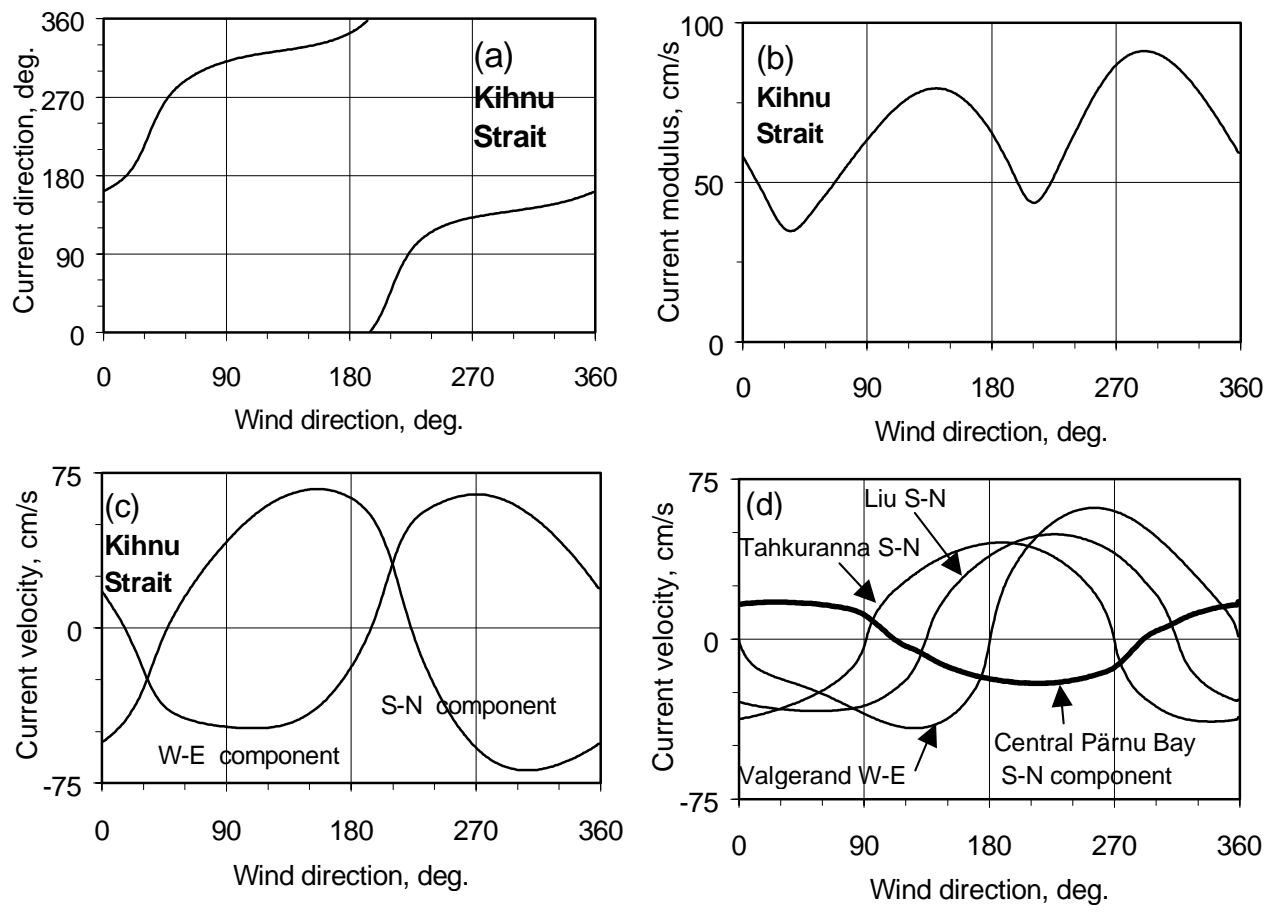

Fig. 5. Modelled current directions (a), modules (b), and velocity components (c) in the Kihnu Strait, and the major velocity components at some points of the Pärnu Bay (d) depending on the direction of the stationary wind with $20 \mathrm{~m} / \mathrm{s}$ modulus. 
patterns are shown in Fig. 6. These steady flow patterns are more "smooth" and regular compared with the occasional snapshots (see, e.g., one in $\left[{ }^{5}\right]$ ).

Considering the dominant, perpendicular to the strait axis SW wind direction, it is not completely clear which of the two directions prevails in the Kihnu Strait. Data about the wind directions for the two semicircles (as defined in Fig. 5c) yield $54 \%$ of cases that favoured eastward currents and $46 \%$ that favoured westward motions in 1999. However, taking into account only strong winds (velocities over $10 \mathrm{~m} / \mathrm{s}$ ), the directional predominance (the rising curve in Fig. 4d) is even more evident: $65 \%$ vs $35 \%$.

The Pärnu Bay seems to have two well-defined and persistent flow regimes (Fig. 6a,b) with switch directions at $90^{\circ}-130^{\circ}$ and $270^{\circ}-310^{\circ}$ (Fig. 5d). The regimes shown in Figs. $6 \mathrm{c}$ and $6 \mathrm{~d}$ represent certain transitional or mixed regimes in the inner Pärnu Bay where two circulation cells develop: the gyre on the lefthand side is anticyclonic and the cyclonic gyre appears over the right side of

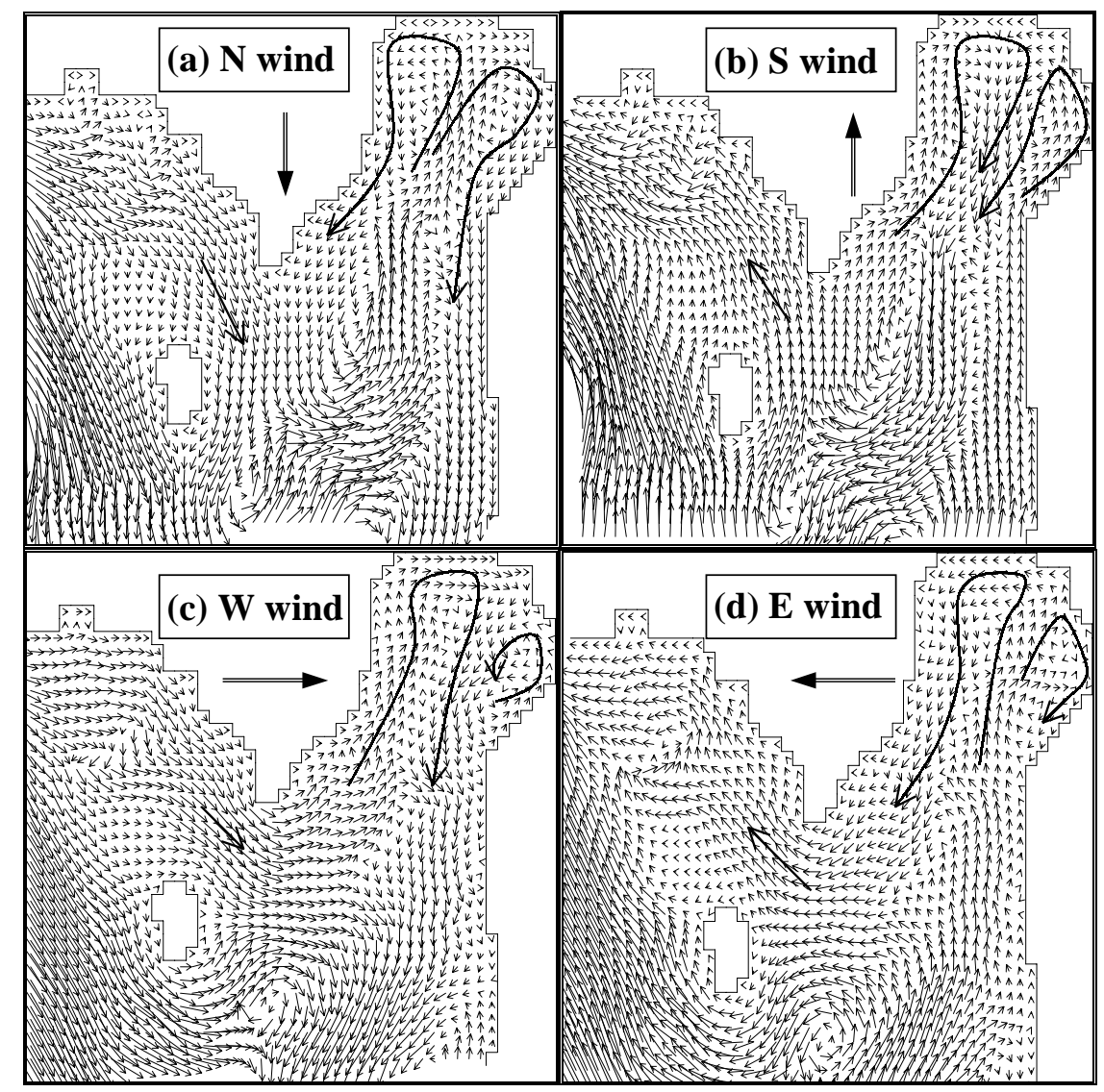

Fig. 6. Flow patterns produced by the $20 \mathrm{~m} / \mathrm{s}$ stationary wind from the north (a), south (b), west (c), and east (d). The longest arrows in the relatively deep SW part of the study area correspond to $5 \times 10^{3} \mathrm{~m}^{3} / \mathrm{s}$ flux integrated from the surface to the bottom. 
the area when looking downwind. Wind drag over the area with oval shape and the distribution of smaller depths near the coast and bigger ones in the central part of the area seems to provide topographical premise for this steady pattern. In general, in any cross-section perpendicular to the wind away from the boundaries, the flow is in the direction of the wind where the basin's depth is less than the average depth, and opposite to the wind where water is deep $\left[^{10,11}\right]$. Similar pattern could appear in the circulation scheme of the whole Gulf of Riga, when not disturbed by other factors $\left[{ }^{12}\right]$. One flow regime (Fig. $6 \mathrm{~b}, \mathrm{c}$ ) prevails over another (Fig. 6a,d) due to local wind statistics. The winds and currents are stronger in the favoured case, firstly, due to the uneven (anisotropic) distribution of strong wind directions above the Baltic Sea $\left[{ }^{13}\right]$, and secondly, due to the smaller influence of the land shade (see also Table 1). In reality, as shown in Fig. 5, such strong $(20 \mathrm{~m} / \mathrm{s})$ north and west winds have never been registered in the Pärnu Bay, whereas SW winds could distinctly exceed the $20 \mathrm{~m} / \mathrm{s}$ value.

The hydrodynamical effect of the Pärnu River inflow (averaging $60 \mathrm{~m}^{3} / \mathrm{s}$ ) is only feebly visible at $2-5$ points nearest to the river mouth. The river flow effect is comparable with that of the marine currents in calm weather, whereas during strong winds the river's share is only about $10 \%$ at a few nearest points. Thus the river has practically no influence on the general flow regime of the bay.

\subsection{Possible influence on coastal processes}

The described flow regime is quite typical for lakes and non-tidal bays. Alongside with the wave action, its outcome reflects on spatial distribution of coastal types $\left[{ }^{14}\right]$. Generally, in Estonia abrasion-accumulation-embayed type of coast dominates $\left[{ }^{15}\right]$. In the outer Pärnu Bay region, relatively flat morainic coasts with cover of shingles, gravel, or erratic boulders dominate along the Kastna-Liu and Tahkuranna sections. Though abrasive potential of the sea is strong there, fine fractions are already largely removed (and transported towards the Pärnu Bay, as it was shown above). Accumulation of sand has formed the famous Pärnu and Valgerand beaches in the end of the Bay $\left[{ }^{15}\right]$. The 130-year old 3-km long breakwaters of Pärnu should prevent the Pärnu port fairway from siltation not only due to the suspended matter carried by the river, but also due to longshore movements of sandy deposits.

The distribution of the modelled velocities in the Valgerand show vast predominance of small velocities regardless of the direction (Fig. 7a). The share of the high velocities seems to be very small, only $0.9 \%$ out of the total number of individual velocity readings were bigger than $45 \mathrm{~cm} / \mathrm{s}$ in 1999 . However, when trying to identify the role of different directions and velocities on the coastal environment, the crucial role of those rare but large velocities was established. The asymmetry between the two tails of the distribution (Fig. 7a) dramatically increases when taking into account the bottom stresses caused by the corresponding velocities, since bottom stress is proportional to the second power of the velocity. Physical quantity which is proportional to work (or energy), which includes velocity in the third power, is shown in Fig. 7b. Calculation of the sums 

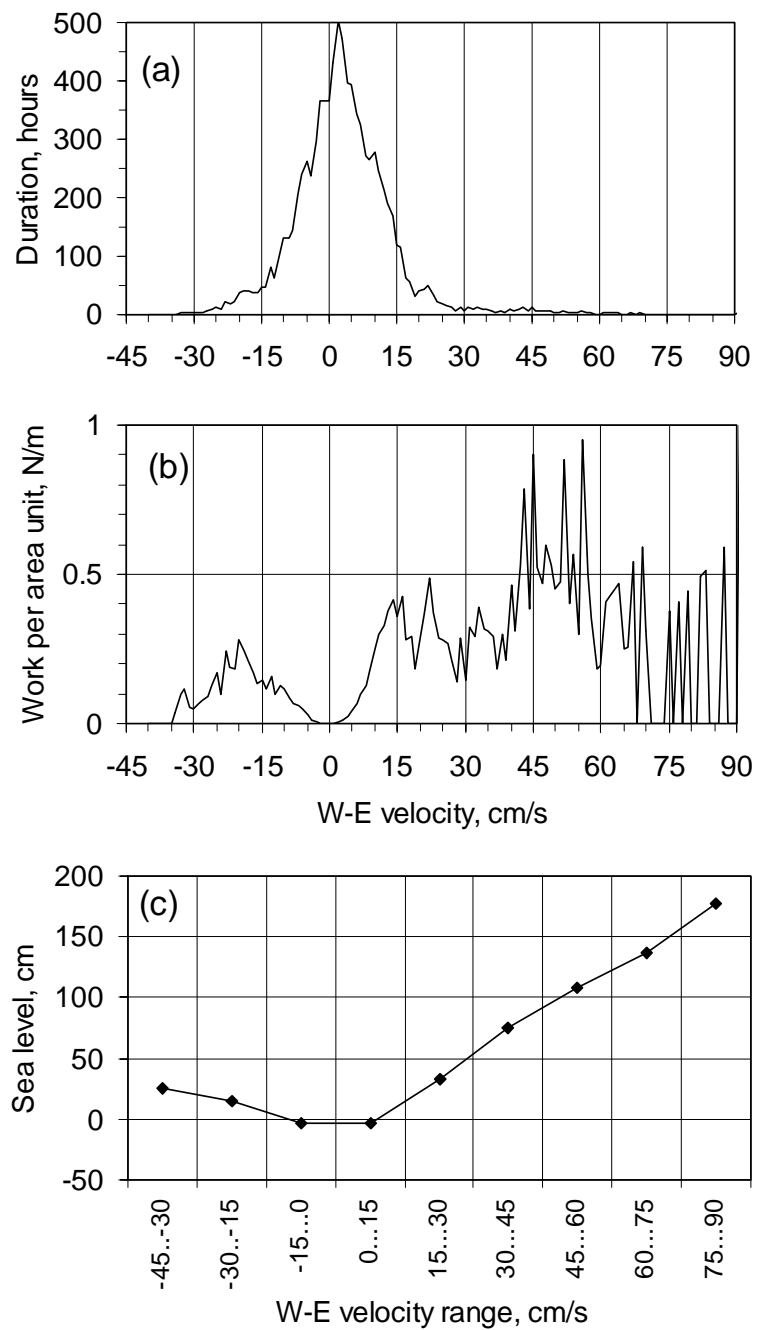

Fig. 7. Distribution of modelled velocities (with $1 \mathrm{~cm} / \mathrm{s}$ increment) in the Valgerand in 1999 (a), works within the same intervals (b), and dependence of the sea level on the current velocities averaged over velocity range with $15 \mathrm{~cm} / \mathrm{s}$ increment (c).

below different sections of the curve reveals that the above-mentioned $0.9 \%$ of the velocities yield about $26 \%$ of the total annual bottom stress and $49 \%$ of the annual work. Moreover, according to literature, small velocities below a certain threshold value, say less than $15 \mathrm{~cm} / \mathrm{s}\left[{ }^{14,16}\right]$, produce stresses which are not able to erode, suspend, and transport sediments at all. They are "wasted". Thus Fig. 7b could be interpreted as follows: the proportion of velocities over the treshold value was only about $13 \%$ out of all velocity readings; $4 \%$ were directed westwards and their corresponding share of "non-wasted" work was about $10 \%$. Eastward velocities between 15 and $45 \mathrm{~cm} / \mathrm{s}$ (8\% of all velocities) produced the 
$35 \%$ share of "non-wasted" work and the remaining eastward velocities over $45 \mathrm{~cm} / \mathrm{s}$ (with $0.9 \%$ frequency) yielded $55 \%$ of the work!

Rephrasing, the current-induced bottom stress in the Valgerand was predominantly directed to the east and about half of the annual work influencing the coast was probably done during the 2-3 most stormy days of the year. In other words, it also means that $6 \%$ of velocities does $94 \%$ of the work. The wind wave contribution to erosion is also the strongest during the stormy periods. In exposed coasts, the bottom stresses generated by the wave action could exceed those of the current-induced ones. Wave models predict that the wave height could reach 3-5 $\mathrm{m}$ in the relatively deep sea area off Kihnu Island and only 1-2 $\mathrm{m}$ in the shallow and sheltered Pärnu Bay. The waves mainly contribute to the cross-shore sediment movements and changes in the beach profile, whereas longshore fluxes are largely produced by the wind driven currents. Longshore currents are also formed in the breaker zone due to the waves approaching the coast under an angle $\left[{ }^{17}\right]$. Anyway, due to the bay's exposition to the prevailing winds (and storms), the two above processes evoking longshore currents are usually not contradictory. They both favour the inflows along the coasts and the compensatory outflow in the bay's trunk zone. They also provide a similar asymmetric geomorphological outcome: the processes favouring the import and accumulation of soft sediments are much more frequent and stronger than the processes of export. In addition to the influence of the regional wind statistics $\left[{ }^{13}\right]$, the local wind is largely shielded by the land in the north. Also, the waves refracting into the bay from the open sea are always higher than those that just depart from the coast. The whole complex of wave-current interaction processes and its relations to bottom properties is quite complicated $\left[{ }^{18-20}\right]$ and should be studied in detail in the future.

An important peculiarity of the Pärnu Bay is associated with the sea level fluctuations: different velocities act at different heights in relation to the waterline (Fig. 7c). Though the highest measured value in 1999 was $146 \mathrm{~cm}$, the model gave few readings above $150 \mathrm{~cm}$, which could not be artifacts. It has been assumed that during rapid sea level changes the Pärnu mareograph shows somewhat lowered values due to its location in the Pärnu River, some $3 \mathrm{~km}$ upstream from the mouth of the river moles $\left[^{5}\right]$. As SW and western storms are associated with sea level rise near Pärnu, the high flow velocities and strong wave action, decisive in coastal erosion events, act 1-2 $\mathrm{m}$ higher than the usual coastal line. This explains the strong bulldozing effect of storms on the sand dunes and coastal woods well away from the ordinary position of the waterfront. Much more frequent, but not very important low velocities (and smaller waves) act around the average waterline.

An additional inference comes for the mixing processes in the Pärnu Bay. It seems that the outflow of riverborne less saline water is statistically favoured along the central part (trunk zone) of the bay, deposition of suspended matter and burial of contaminants should be expected along the trunk zone due to the smaller velocities compared to those near the coast. 


\section{CONCLUSIONS}

Based on 2D simulations, forced both by realistic and stationary wind regimes, the average flow velocities in the study area could be estimated as $4-11 \mathrm{~cm} / \mathrm{s}$ and the maximum values could reach $90 \mathrm{~cm} / \mathrm{s}$. Though the temporal variations of the currents are fairly large, two major and quite regular flow patterns with two circulation cells alternate in the Pärnu Bay. The more frequent one has inflows along the Liu and Tahkuranna coasts and outflows along the axis of the Bay.

Determined by the directional distribution of winds, SE currents (yielding annual sum of flows $31 \mathrm{~km}^{3}$ in 1999) dominated over the NW direction $\left(15 \mathrm{~km}^{3}\right)$ in the Kihnu Strait in 1999.

In the region of Valgerand, the current-induced bottom stresses are predominantly directed to the east (90\% of work) and roughly half of the currents' annual work attacking the coast is done during the 2-3 stormy days of the year. Decisive factors in coastal erosion and longshore sand displacement events, the high velocities together with waves action, operate 1-2 $\mathrm{m}$ above the average waterline height in the Pärnu Bay. The influence of the currents, waves and sea level fluctuations should be simultaneously modelled in the future; however, their geomorphological outcome in the Pärnu Bay is likely to be equidirectional.

\section{ACKNOWLEDGEMENTS}

This study was supported by the Estonian Science Foundation grant No. 4057. Special thanks are due to Dr. Tarmo Kõuts for providing the forcing data for 1999.

\section{REFERENCES}

1. Suursaar, Ü. and Tenson, J. Hydrochemical regime and productivity of the Pärnu Bay in 1968-1996. In More Studies on the Water Exchange and the Nutrients of the Gulf of Riga. EMI Report Series, 9 (Suursaar, Ü. and Astok, V., eds.). Tallinn, 1998, 91-117.

2. Suursaar, Ü., Kullas, T., and Otsmann, M. A model study of the sea level variations in the Gulf of Riga and the Väinameri Sea. Continental Shelf Res., 2002. Forthcoming.

3. Pärn, T. Kihnu väina merepark. Keskkonnatehnika, 1997, 5, 12-13.

4. Kullas, T., Otsmann, M., and Suursaar, Ü. Comparative calculations of flows in the straits of the Gulf of Riga and the Väinameri. Proc. Estonian Acad. Sci. Eng., 2000, 6, 284-294.

5. Suursaar, Ü., Kullas, T., and Otsmann, M. Hydrodynamical modelling of sea levels in the Väinameri and Pärnu Bay. Proc. Estonian Acad. Sci. Eng., 2001, 7, 221-233.

6. Smith, S. D. and Banke, E. G. Variation of the sea surface drag coefficient with wind speed. Quart. J. Royal Meteorol. Soc., 1975, 101, 665-673.

7. Berzinsh, V., Bethers, U., and Sennikovs, J. Gulf of Riga: bathymetric, hydrological and meteorological databases, and calculation of the water exchange. Proc. Latvian Acad. Sci. $B, 1994,7 / 8,107-117$. 
8. Otsmann, M., Suursaar, Ü., and Kullas, T. The oscillatory nature of the flows in the system of straits and small semienclosed basins of the Baltic Sea. Continental Shelf Res., 2001, 21, $1577-1603$.

9. Kask, J. Rannapurustused Pärnu lahes (talv 1999/2000). Eesti Geoloogiakeskus, Tallinn, 2000. http://www.seiremonitor.ee/alam/05/?leht=05_4_rannapurustused.

10. Birchfield, G. E. Horizontal transport in a rotating basin of parabolic depth profile. J. Geophys. Res., 1967, 72, 6155-6163.

11. Csanady, G. T. Wind-induced barotopic motions in long lakes. J. Phys. Oceanogr., 1973, 3, 429-438.

12. Raudsepp, U. Wind-driven Circulation in the Gulf of Riga. Dissertationes Geophysicales Universitatis Tartuensis, 14. Tartu University Press, Tartu, 2001.

13. Soomere, T. and Keevallik, S. Anisotropy of moderate and strong winds in the Baltic Proper. Proc. Estonian Acad. Sci. Eng., 2001, 7, 35-49.

14. Kuenen, P. H. Marine Geology. J. Wiley, New York, 1950.

15. Orviku, K. Estonian Seacoasts. Estonian Academy Publishers, Tallinn, 1974 (in Russian).

16. Huttula, T. Modelling the Transport of Suspended Sediment in Shallow Lakes. Thesis. University of Helsinki, 1994.

17. Ruessink, B. G., Miles, J. R., Feddersen, F., Guza, R. T., and Elgar, S. Modeling the alongshore current on barred beaches. J. Geophys. Res., 2001, 106, 22451-22463.

18. Musielak, S. Main morpho-lithodynamical regularities governing the development of sandy beaches. In Main Regularities and Tendencies of the Baltic Sea Shoreline Migration During the Past 100 Years (Orviku, K., ed.). Estonian Academy of Sciences, Tallinn, 1992, 63-68 (in Russian).

19. Liiv, T. and Liiv, U. Saaremaa deep harbour layout design and computer simulation of the wave climate and sediment transport. Proc. Estonian Acad. Sci. Eng., 2001, 7, 174-192.

20. Jones, J. E. and Davies, A. M. Influence of wave-current interaction, and high frequency forcing upon storm induced currents and elevations. Estuarine, Coastal and Shelf Science, 2001, 53, 397-413.

\section{Pärnu lahe ja Kihnu väina hoovuste modelleerimine}

\section{Ülo Suursaar, Tiit Kullas ja Mikk Otsmann}

Pärnu lahe ja Kihnu väina hoovuste statistilisi iseärasusi on uuritud 2D hüdrodünaamilise mudeli abil, arvestades nii 1999. aasta vaatlusandmeid kui ka erinevaid statsionaarseid tuulerežiime. Pärnu lahes esineb kaks põhilist voolamisrežiimi, millest levinuima järgi on sissevool piki Liu ja Tahkuranna rannikut ning väljavool lahe keskosas. Nii Kihnu väinas kui ka Valgeranna lähistel domineerib idasuunaline voolamine. Rannaerosiooni ja setete transpordi suhtes olulised suured hoovuse kiirused toimivad (koos tormilainetusega) Pärnu lahes 1-2 m keskmisest rannajoonest kõrgemal ning umbes pool hoovuste tehtavast randa muutvast aastasest tööst toimub kõigest 2-3 tormisema päeva jooksul. 